\title{
In Vitro Study: Combination of Herbs and Probiotics as A Alternative Antibiotic Growth Promoters
}

\author{
Vinsa Cantya Prakasita ${ }^{1}$, Agnesia Endang Tri Hastuti Wahyuni ${ }^{2 *}$
}

${ }^{1}$ Department Biology, Faculty of Biotechnology, Duta Wacana Christian University, Jl. Dr. Wahidin Sudirohusodo No.5-25, Kotabaru, Gondokusuman, Yogyakarta, Daerah Istimewa Yogyakarta 55224, Indonesia

${ }^{2}$ Department Microbiology, Faculty of Veterinary Medicine, University of Gadjah Mada, Jl. Fauna No. 2, Caturtunggal, Depok, Sleman, Daerah Istimewa Yogyakarta 55281, Indonesia

DOI: $10.36347 /$ sjavs.2020.v07i08.004

| Received: 18.08.2020 | Accepted: 26.08.2020 | Published: 28.08.2020

*Corresponding author: Agnesia Endang Tri Hastuti Wahyuni

\section{Abstract}

Antibiotic growth promoters (AGP) are widely used in animal feed for feed efficiency, spur growth, and productivity of livestock in a short time and minimize mortality by preventing infection. Now, its use has been officially banned worldwide. As a result of this ban, many breeders or animal feed producers are looking for solutions in various ways such as the addition of herbs, probiotics, and/or a combination of both, but there are still few scientific studies on the role of herbs, probiotics, and/or a combination of both as alternatives to AGP. This study aimed to determine the role of herbs in the growth of probiotics. The herbs used were ginger (Zingiber officinale), turmeric (Curcuma longa), kencur (Kaempferia galanga), temulawak (Curcuma zanthorrhiza), and temu ireng (Curcuma aeruginosa), while the probiotics used were Bifidobacterium longum, B. bifidum, Bacillus sp., and Saccharomyces cereviciae. The Kierbybauer disc diffusion method was used in this study to determine the effect of herbs on probiotic growth. Chloramphenicol disc was used as a positive control, then the culture media was incubated in the microaerophilic condition, temperature $37^{\circ} \mathrm{C}$ for $24 \mathrm{~h}$. Observation and measurement of the diameter of the growth zone and the inhibition zone of probiotics were carried out after incubation. The results of this study prove that herbs do not inhibit the growth of probiotics. Herbal can be prebiotic candidates that can support probiotic growth. The herbal-probiotic combination can potentially replace AGP in animal feed.

Keywords: Antibiotic growth promoters, ginger, turmeric, kencur, temulawak, temu ireng, Bifidobacterium longum, B. bifidum, Bacillus sp., Saccharomyces cereviciae.

Copyright @ 2020: This is an open-access article distributed under the terms of the Creative Commons Attribution license which permits unrestricted use, distribution, and reproduction in any medium for non-commercial use (NonCommercial, or CC-BY-NC) provided the original author and source are credited.

\section{INTRODUCTION}

Antibiotic growth promoter (AGP) is widely used in animal feed for feed efficiency, stimulates growth and productivity in a short time, and minimizes mortality to prevent infection management [1, 2, 3]. The use of AGP in livestock has a high contribution to the incidence of antibiotic resistance in humans or livestock [4]. Antibiotics will be absorbed into livestock products so that antibiotics are indirectly obtained even in low concentrations. The use of antibiotics at the subtherapeutic level can increase bacterial resistance and chemical residues and can cause allergic effects in humans $[5,6]$. With the negative impact of using AGP, natural ingredients are widely used as an alternative to feed additives.

Natural rhizomes such as ginger, turmeric, kencur, temulawak, and temu ireng are types of spices that are often used in everyday life. Many of the beneficial pharmacological effects of this rhizome, such as antimicrobial, anti-inflammatory, antioxidant, cancer prevention, and immunomodulators. This herbal plant from the Zingiberaceae family is also useful for increasing livestock production performance by maximizing feed efficiency [7, 8].

Apart from herbs, alternative feed additives such as probiotics are also widely used. Probiotics are live microorganisms in the form of non-pathogenic bacteria or yeast that help balance the intestinal microflora to maintain animal health and production [9, 10]. The positive biomedical effects of probiotics consist of their ability to inhibit pathogenic microbes in the digestive tract, optimize digestion, and stimulate the immune system [11]. Probiotics also function as antitumor, anti-allergenic, and function as anti-cholesterol [12]. Bacteria that ferment lactic acid, such as Bifidobacterium longum and Bifidobacterium bifidum, spore-producing bacteria (Bacillus sp.), including 
Saccharomyces cerevisiae are known to be able to simulate various kinds of immune systems and improve performance [13]. Apart from being non-pathogenic, microorganisms are selected on the basis of survival and factors in the gastrointestinal environment [14].

The use of a combination of herbs and probiotics as functional feed has not been widely studied. Each product has benefits and high selling value, but if combined, it must have a synergistic effect. Herbs are an economical product but have an antimicrobial effect that allows probiotic microbes to die when combined. This study aims to determine the effect of herbs on the growth of probiotic microbes in vitro.

\section{MATERIALS AND METHODS Probiotic Bacterial Culture}

The probiotics used were Bifidobacterium longum, B. bifidum, Bacillus sp., and Saccharomyces cereviciae. Bifidobacterium longum, B. bifidum, and Bacillus sp. cultured on de Man Rogosa Sharpe (MRS, Merck $^{\mathrm{TM}}$ ) broth media and incubated in microaerophilic conditions, temperature $37^{\circ} \mathrm{C}$ for $24-48 \mathrm{~h}$, while $S$. cereviciae was cultured on Sodium Dextrose Agar $\left(\mathrm{SDA}\right.$, Merck $^{\mathrm{TM}}$ ) medium. Cultures were centrifuged at $10,000 \mathrm{rpm}$ for 10 minutes, then resuspended with Phosphate Buffered Saline (PBS pH 7.4, Sigma ${ }^{\mathrm{TM}}$ ) with a concentration equivalent of $1.5 \times 10^{8} \mathrm{CFU} / \mathrm{mL}$ [15].

\section{Herbal Solution}

Solution extracts of ginger (Zingiber officinale), turmeric (Curcuma longa), kencur (Kaempferia galanga), temulawak (Curcuma zanthorrhiza), and temu ireng (Curcuma aeruginosa) were obtained from CV. Pradipta Paramita (herbal feed additive company). Individual herbal solutions and/or combinations of two, three, four, and all herbal solutions were used in this study to determine each and/or combination of herbs for the growth of probiotics.

\section{Effect of Herbs on Probiotics}

The effect of ginger, turmeric, kencur, temulawak, and temu ireng on the four probiotics was carried out using the Kierby-Bauer disc diffusion method with some modifications [16]. Twenty microliters of herbal extracts were immersed on a blank disc $\left(\right.$ Oxoid $\left.^{\mathrm{TM}}\right)$ and placed on the surface of Mueller Hilton Agar (MHA, Merck ${ }^{\mathrm{TM}}$ ) media which had been cultured for Bifidobacterium longum, B. bifidum, Bacillus sp., and Saccharomyces cereviciae, respectively. Chloramphenicol disc (C 30 $\mu$ g, Oxoid ${ }^{\mathrm{TM}}$ ) was used as a positive control. The culture media was incubated in the microaerophilic condition, temperature $37^{\circ} \mathrm{C}$ for $24 \mathrm{~h}$.

\section{DATA ANALYSIS}

Observation and measurement of the diameter of each zone were carried out after incubation. The zone of inhibition (clear zone) surrounding the disc illustrates the presence of herbal antibacterial activity against probiotics, while the growth zone around the disc indicates the ability of the herbal extract to support probiotic growth. The results of the growth zone and inhibition zone were analyzed descriptively.

\section{RESULT AND DISCUSSION}

The effect of herbs on probiotic growth was carried out by using the Kierby-Bauer disc diffusion method to determine the presence/absence of an inhibition zone or a zone of probiotic growth. The results of the study showed that both individual and combination herbs were able to support probiotic growth in the presence of a growth zone around the disc. The growth zone of each probiotic varies in each herbal disc. The diameter of the growth zone and the zone of inhibition are shown in Table 1.

The largest diameter of $B$. longum growth zone (37 $\mathrm{mm})$ is around disc $\mathrm{R}$, which consists of a combination of all herbs (ginger, turmeric, kencur, temulawak, and temu ireng). The B. longum growth zone around discs A, B, C, D, E containing individual herbs could not be measured. This is due to the uneven growth of bacteria, but all the herbs used in this study did not inhibit growth when compared to the inhibition zone in the control, chloramphenicol disc $(30 \mathrm{~mm})$.

Similar to the growth of B. longum in the $\mathrm{R}$ disc area, a combination of ginger, turmeric, kencur, temulawak, and temu ireng also supports the growth of B. bifidum (Fig 1) and Bacillus sp. (33 mm; $28 \mathrm{~mm}$ ). Growth of $B$. bifidum was supported by all herbs used in this study, either individually or in combination. The growth zone of Bacillus sp. on disc $\mathrm{G}$ and $\mathrm{H}$ cannot be measured because the bacterial growth is evenly distributed around the disc. This shows that the herbal combination of $\mathrm{G}$ (ginger, turmeric, temulawak) and $\mathrm{H}$ (ginger, turmeric, temu ireng) has no effect on the growth of Bacillus sp.

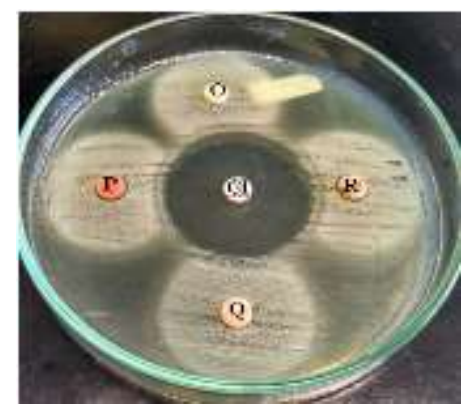

Fig-1: Bifidobacterium bifidum growth zone around disc $\mathrm{O}$ (ginger, turmeric, temulawak, temu ireng), disc $\mathbf{P}$ (ginger, kencur, temulawak, temuireng), disc Q (turmeric, kencur, temulawak, temu ireng), disc $\mathbf{R}$ (ginger, turmeric, kencur, temulawak, temu ireng) and chloramphenicol inhibition zone around disk $\mathrm{Cl}$. 
In contrast to the three previous bacterial growth zones, $S$. cerevisiae growth was supported by $\mathrm{K}$ discs containing turmeric, kencur, and temulawak (34 $\mathrm{mm})$. This yeast growth is strictly confined to discs containing individual herbs. Herbs can increase the growth of probiotics, but the benefits in the form of a combination of herbs will increase the synergistic effect.

Table-1: The diameter of the growth zone of herbs and the inhibition zone of antibiotics against Probiotics

\begin{tabular}{|c|c|c|c|c|c|c|c|c|c|c|c|c|c|c|c|c|c|c|c|}
\hline \multirow[t]{2}{*}{ Probiotic } & \multicolumn{18}{|c|}{$\begin{array}{l}\text { The diameter of the growth zone } \\
\text { (mm) }\end{array}$} & \multirow{2}{*}{$\begin{array}{c}\text { The diameter } \\
\text { of the } \\
\text { inhibition } \\
\text { zone (mm) }\end{array}$} \\
\hline & A & B & C & D & $\mathbf{E}$ & $\mathbf{F}$ & $\mathbf{G}$ & $\mathbf{H}$ & I & $\mathbf{J}$ & $\mathbf{K}$ & $\mathbf{L}$ & M & $\mathbf{N}$ & $\mathbf{O}$ & $\mathbf{P}$ & Q & $\mathbf{R}$ & \\
\hline B. longum & \# & $\#$ & $\#$ & $\#$ & $\#$ & 22 & 27 & 31 & 25 & 30 & 25 & 36 & 33 & 32 & 26 & 25 & 30 & 37 & 30 \\
\hline B. bifidum & 21 & 25 & 21 & 17 & 23 & 20 & 23 & 22 & 23 & 22 & 20 & 31 & 31 & 30 & 22 & 22 & 17 & 33 & 28 \\
\hline Bacillus sp. & 12 & 18 & 17 & 14 & 15 & 15 & $*$ & $*$ & 17 & 20 & 25 & 26 & 25 & 26 & 27 & 27 & 25 & 28 & 24 \\
\hline S. cerevisiae & $\#$ & $\#$ & $\#$ & $\#$ & $\#$ & 10 & 11 & 31 & 33 & 31 & 34 & 28 & 30 & 25 & 11 & 10 & 11 & 26 & 20 \\
\hline
\end{tabular}

${ }^{\#}$ Growth zones cannot be measured; *Probiotics grow evenly

$\mathrm{A}=$ turmeric; $\mathrm{B}=$ ginger; $\mathrm{C}=$ kencur; $\mathrm{D}=$ temu ireng; $\mathrm{E}=$ temulawak; $\mathrm{F}=$ ginger, turmeric, kencur; $\mathrm{G}=$ ginger, turmeric, temulawak;

$\mathrm{H}=$ ginger, turmeric, temu ireng; $\mathrm{I}=$ ginger, kencur, temulawak; $\mathrm{J}=$ ginger, kencur, temu ireng; $\mathrm{K}=$ turmeric, kencur, temulawak; $\mathrm{L}=$ turmeric, kencur, temu ireng; $\mathrm{M}=$ ginger, turmeric, kencur, temulawak; $\mathrm{N}=$ ginger, turmeric, kencur, temu ireng; $\mathrm{O}=$ ginger, turmeric, temulawak, temu ireng; $\mathrm{P}=$ ginger, kencur, temulawak, temu ireng; $\mathrm{Q}=$ turmeric, kencur, temulawak, temu ireng; $\mathrm{R}=$ ginger, turmeric, kencur, temulawak, temu ireng; $\mathrm{S}=$ chloramphenicol disc

The results of this study are consistent with the results of a study conducted by Prakasita et al. [17] which proved that probiotic bacteria, Lactobacillus acidophilus and L. brevis were supported by their growth in media containing extracts of ginger, red ginger, and turmeric. The potential of herbs as prebiotic candidates by supporting probiotic growth is influenced by the carbohydrate content in the extract. Carbohydrates can be a good growth medium for probiotics. The study conducted by Rahminiwati et al. [18] explained that turmeric aquadest extract contains monosaccharides which are proven to be potential prebiotics to increase the growth of L. plantarum. Zhou et al. [19] and Molan et al. [20] explained that the polyphenol content of herbal extracts had a high antioxidant activity to combat free radicals. Polyphenols play a role in dealing with oxidative stress generated by metabolic activity by providing a microaerophilic environment for probiotics.

\section{CONCLUSION}

Herbs solutions of ginger, turmeric, kencur, temulawak, and temu ireng which have antimicrobial benefits do not inhibit the growth of bacteria and yeast is a probiotic candidate. The rhizomes from the Zingiberceae family can actually support the growth of probiotic microorganisms. Thus, ginger, turmeric, kencur, temulawak, and temu ireng can be used as prebiotic candidates that can be applied with probiotics into a functional feed called synbiotics. Further research regarding the effects of this synbiotic in the animal body needs further investigation.

\section{ACKNOWLEDGEMENT}

Thanks to the Faculty of Biotechnology, Duta Wacana Christian University and the Faculty of Veterinary Medicine, University of Gadjah Mada has provided the Research Grant Funds, so that this research can be carried out well.

\section{REFERENCES}

1. Mitchell JM, Griffiths MW, McEwen SA, McNab WB, Yee AJ. Antimicrobial drug residues in milk and meay: causes, concerns, prevalence, regulations, test, and, test performance. Journal of Food Protection. 1998; 61(6): 742-756.

2. Radetsky P. Last days of the wonder drugs. Discover November. 1998; 76-85.

3. Van Den Bogaard AE, Stobberingh EE. Epidemiology of resistance to antibiotics links between animals and humans. International Journal of Antimicrobial Agents. 2000; 14: 327-335.

4. Barton MD. Antibiotic use in animal feed and its impact on human health. Nut. Res. Rev. 2000; 13: $1-22$.

5. Greathead H. Plants and plant extracts for improving animal productivity. Proc Nutr Soc. 2003; 62: 279-290.

6. Kompiang IP. Pemanfaatan mikroorganisme sebagai probiotik untuk meningkatkan produksi ternak unggas di Indonesia. Pengembangan Inovasi Pertanian. 2009; 2: 177-191.

7. Srinivasan K. Ginger rhizomes (Zingiber officinale): a spice with multiple health beneficial potentials. Pharma Nutrition. 2017; 5: 18-28.

8. Chakraborty B, Nath A, Saikia H, Sengupta M. Bacterial activity of selected medical plant against multidrug resistant bacterial strains from clinical isolates. Asian Pac J Trop Med. 2014; 7(Suppl 1): S435-S441.

9. Abdel-Aziz NA, El-Adawy M, MariezcurrenaBerasain MA, Salem AZM, Olivares-Pérez J, Kholif AE, Borhami BE. Effects of exogenous enzymes, Lactobacillus acidophilus or their combination on feed performance response and carcass characteristics of rabbits fed sugarcane 
bagasse. Journal of Integrative Agriculture. 2015; 14: 544-549.

10. Elghandour MMY, Salem AZM, Martínez Castañeda JS, Camacho LM, Kholif AE, Vázquez Chagoyán JC. Direct-fed microbes: a tool for improving the utilization of low quality roughages in ruminants. Journal of Integrative Agriculture. 2015; 14: 526-533.

11. Mateova S, Gaálová M, Šály J, Fialkovičová M. Investigation of the effect of probiotics and potentiated probiotics on productivity of laying hens. Czech. J. Anim. Sci. 2009; 54(1): 24-30.

12. Soccol CR, de Souza Vandenberghe LP, Spier MR, Medeiros ABP, Yamaguishi CT, Lindner JD, Pandey A, Thomaz-Soccol, V. The potential of probiotics: a review. Food Technol. Biotechnol. 2010; 48(4): 413-434.

13. Patterson R, Nerren J, Kogut M, Court P, Villarreal-Ramos B, Seyfert HM, Dalby P, Werling D. Yeast-surface expressed BVDV E2 protein induces a Th1/Th2 response in naïve $T$ cells. Dev. Comp. Immunol; 2011.

14. Collins J, Thornton G, Sullivan G. Selection of Probiotic Strains for Human Applications. International Dairy Journal. 1998; 8(5-6): 487-490.
15. Niamsa N, Sittiwet C. Antimicrobial activity of Curcuma longa aqueous extract. Journal of Pharmacology and Toxicology. 2009; 4(4): 173177.

16. Bauer AW, Kirby MW, Sherris JC, Turck M. Antibiotic susceptibility testing by a standardized single disc method. American Journal Clinical Pathology. 1966; 45(4): 493-496.

17. Prakasita VC, Asmara W, Widyarini S, Wahyuni AETH. Combinations of herbs and probiotics as an alternative growth promoter: an in vitro study. Veterinary World. 2019; 12: 614-620.

18. Rahminiwati M, Rahmatullah S, Batubara I, Achmadi SS. Potensi ekstrak rimpang kunyit sebagai prebiotik pemacu pertumbuhan Lactobacillus plantarum secara in vitro. Jurnal Ilmu Kefarmasian Indonesia. 2014; 12(1): 37-42.

19. Zhou Q, Wang S, Yang G, Zhao W, Li HL. Development and evaluation of herbal formulation with antipathogenic activities and probiotics stimulatory effect. Journal Integrative Agriculture. 2016; 15(5): 1103-1111.

20. Molan AL, Flanagan J, Wei W, Moughan PJ. Selenium containing green tea has higher antioxidant and prebiotic activities than regular green tea. Food Chemistry. 2009; 114: 820-835. 